\title{
İletişim Çağında Yalnızlığa Özlem: Post-Apokaliptik Sinema ve Bird Box
}

Dr. Öğr. Üyesi Emre AŞILIOĞLU

Mardin Artuklu Üniversitesi

GSF, Sinema ve Televizyon Bölümü

emre.asilioglu@hotmail.com

ORCID: 0000-0002-4857-0657
Geliş Tarihi/Received: 05.08.2019 Kabul Tarihi/Accepted: 03.09.2019

Yayın Tarihi/Published: 29.09.2019

\section{Öz}

Günümüzde kıyamet sonrası dünya tasvirlerinin yapıldığı ve bu apokaliptik sonralarda, sürekli çatışma halindeki distopik toplumsal düzenlerin kurulduğu içeriklere sahip sinema filmlerinin sayısının giderek arttığı gözlemlenmektedir. Bunun nedenlerini, kapital sistemin küresel çapta içine düştüğü ekonomik, ekolojik krizlerle, küresel ısınmanın artık gözle görülür etkileriyle, bölgesel savaşların, çatışmaların artmasıyla ve bu eksende silahlanma yarışlarının tüm 20. Yüzyılda olduğu gibi hız kesmeden devam etmesiyle, kitle iletişim araçları aracilığıyla, 'bilgi'ye dair dezenformasyon ve manipülasyonun aşıı uçlarda seyretmesiyle ilişkili olarak ele alabiliriz. Yine bilimsel-teknolojik gelişmelerin aldığı seyir, laboratuvarlarda geliştirilen, ne türden etkilerinin olacağı henüz kestirilemeyen virüs türleri de, bu nedenlerle ilişkili olarak ele alınabilir. İnsan türünün gelişim arzusu, diğer yüzünde kendi kendinin sonunu da getirme şeklindeki fantazileri de beslemektedir. Bu araştırma bu nitelikte yapımların temelini oluşturan kültürel ve tarihsel derinliği incelerken, bu türe dahil edilen edebiyat uyarlaması 'Bird Box' adlı yapım bu temellendirme ile analiz edilmiştir.

Anahtar Kelimeler: Bird Box, Post-Apokaliptik Sinema, Korku Filmleri.

Aşlıoğlu, E. ve Özcan, Ş. (2019). İletişim Çağında Yalnızlığa Özlem: Post-Apokaliptik Sinema ve Bird Box. ARTS: Artuklu Sanat ve Beşeri Bilimler Dergisi, 2, ss. 70-90. 


\title{
Longing for Loneliness in the Age of Communication: Post-Apocalyptic Cinema and Bird Box
}

\begin{abstract}
Today, it is observed that there is an increase in the number of the movies, in which post-apocalyptical world depictions are made and in these post-apocalyptical futures there are constantly conflicting dystopic social orders. The reasons for this may be considered in relation to the economic and ecological crises in which the capital system falls globally; the visible effects of global warming; the increase in regional wars, conflicts and on this axis, the proliferation of arms races as in the 20th century; extreme ends of the disinformation and manipulation concerning 'information' through mass media. Therewithal, the process of scientific-technological developments, the types of viruses developed in laboratories, and which effects can not be predicted yet, may be considered in relation to these reasons. Human desire for development nurtures the fantasies of self-destruction on the other side. While this research examines the cultural and historical depth that constitutes the basis of such productions, the literary adaptation 'Bird Box' included in this genre is analyzed with this grounding
\end{abstract}

Keywords: Bird Box, Post- Apocalyptic Cinema, Horror Films. 


\section{arts $=$}

\section{Gíriş}

Sinemanın türleri arasında korku sineması en popüler türlerden bir tanesidir. Sinema konusunda yazılar yazan pek çok düşünür, korku sinemasının izleyicinin güvenli alanlarından ayrımadan korkularıyla yüzleşmesini sağladığı gerekçesiyle sevildiğini ifade etmektedirler. Seyirciler bu sayede arınırlar (katarsis). Bu özelliğinin dışında korku filmleri bireylerin veya toplumların kaygı, endişe ve korkularından kodlar barındırdığı için çeşitli bakış açılarıyla incelemeye değer görülmektedir (Topçu, 2001, s. 127).

Korku türündeki sinema eserlerinin genel olarak üç ana yapıda karşımıza çıktığını söyleyebiliriz. Bunlardan ilkinde izleyicinin karşısına kurt adamlar, vampirler gibi varoluşlarının temelinde doğanın bulunduğu ama doğaüstü kabul edilen yaratıklar çıkmaktadır. İkinci kategoride ise ünlü yönetmen Alfred Hitchcock'un bazı filmlerinde olduğu gibi psikolojik korku unsurlarının kullanıldığı söylenebilir. Bu iki temel korku sineması unsurunun dışında kimi zaman bazı doğa üstü güçlere sahip olsa bile seri katil filmleri de bu türe dahil edilmektedir (Ekinci, 2015, s. 237) Günümüz eserlerinde kurt adamların veya şeytanların yerini, ağırlıklı olarak bilim ve teknolojiye bıraktığını gözlemleyebiliriz. İnsanların uyum sağlayamayacağı bir hızda gelişen bilim ve teknoloji nedeniyle kişiliklerini kaybettikleri ileri sürülmektedir. Tıpkı geçmişin Kont Dracula'sı gibi modern bilim, birey üzerinde hipnotik bir etki yapabilmektedir (Oskay, 2014 , s. 139). Bu filmlerin dışında ise kitlesel yok oluş öykülerinin anlatılığı filmlerin popülerliğinin milenyum ile birlikte artığını söyleyebiliriz. Her ne kadar böylesi sinema filmleri uzunca bir süredir yapılıyor olsa bile özellikle son on yılda bu tür yapımların sayısının hızlıca arttığını gözlemleyebiliriz. Bu tür yapımlar bir takım özellikleri ile geleneksel korku veya gerilim sinemasının temel özellikleri ile benzerlik gösterseler de seyirciyi korkutmakta kullandıkları kaygıların inşa ediliş biçimiyle büyük farklara sahiptir diyebiliriz. Örneğin geleneksel korku sinemasının kullanmış olduğu korkular bireysel nitelikler taşırken, post apokaliptik sinema filmlerinin temelini oluşturan korkuların özünde modern dünyanın ve onun temel kurumlarının ortadan kalkması öncelikli bir unsur olarak sunulabilmektedir.

Bu araştırma; özelikle son yıllarda popülerleşen post-apokaliptik sinema filmlerinin temellendiği yapıyı değerlendirmeyi amaçlamaktadır. Ayrıca 2018 yılında seyirci ile buluşan, yönetmenliğini Susanne Bier' in yaptığı roman uyarlaması "BirdBox" adlı filmin bu tür içerisindeki yerini tartışmaktadır. 


\section{Değişen Canavar İmgesi}

Yaşadığımız yüzyılda yaşanan dönüşümlerle birlikte toplumlara veya bireylere sunulan sanatsal ürünlerinin hem biçimsel yapısında, hem de konuların ele alınış biçimlerinde değişimler yaşandığı gözlemlenmektedir. Bu dönüşüm sürecinden masallar/öyküler de etkilenmiştir. Örneğin Yunan mitolojisinde yer alan Minotor gibi insan ve hayvanın tek bir bedende tasvir edildiği yaratıkların benzerleri günümüzde sinema, çizgi roman, fotoğraf gibi sanatsal üretimlerde farklı yapılarda ve alışılmadık niteliklerle yüklenmiş bir şekilde karşımıza çıkabilmektedir. Bu açıdan günümüzün "yaratıkları", geçmişin izlerini barındırsalar bile, toplumsallık zemininde yaşanan değişimler sonucunda farklı özelliklere sahip oldukları görülmektedir. Yakın döneme kadar doğa ile ilişkili 'canavar' tasvirleri sunulurken ya da doğaya meydan okumanın neticesinde, doğanın bir intikamcı olarak geri dönüşünü imlemeyle ilişkili bir canavar imgesi söz konusu edilirken, gelinen aşamada, algısal düzlemde değişen dünya yapısı ile birlikte, canavarların da doğa ile bağları kaybolmuş, muğlaklığa yönelmişlerdir. Günümüzde insanlarının her geçen gün doğa ile ilişkisinin giderek azalıyor olduğu düşüncesi, bu görüşü temellendiren bakış açılarından birini oluşturmaktadır.

20. yüzylın film endüstrisinin korku/fantastik veya bilim-kurgu türlerinde yer alan "canavar" imgesi incelendiğinde, bu imgenin bir takım temel formlar ve kavramlar etrafında kümelendiği görülmektedir. Söz konusu film türlerinde gördüğümüz daha geleneksel, doğa temelli vampirler, kurt adamlar, mumyalar gibi korku mitleri zaman içerisinde yerini zombiler, uzaylılar gibi farklı türlere bırakmıştır. Günümüzde ise; korkunun imgeleri tekrar değişmekte ve insan, teknoloji ve bilinmezlik temelli bir yapıda kendini hissettirmektedir. Bu yeni durumu 1. ve 2. Dünya Savaşlarındaki alt edilmesi gereken kötücül düşman imgesinin ve bütün bir soğuk savaş döneminin tehditkar "öteki"sinin, sahne önünde sembolleştirilmesiyle ilişkili olarak ele alabiliriz. Aynı şekilde, psikanalitik düzeyde, modern toplumların bastıılan bilinçaltının geri dönmesi de "canavar" imgesinde temellenir. Ancak 21. yüzylın yaşadığımız bu ilk çeyreğinde ise, korku/fantastik veya bilim-kurgu türlerinde, sahnede görünmeyen bir bilinmezin, nereden geldiği belli olmayan bir tehdidin yarattığı nedenden dolayı, küresel çapta, kitlesel yok oluşumuzun gerçekleştiricisi olan, apokaliptik bir dünya imgesini görselleştiren yeni bir "canavar" imgesi izleyiciye sunulmaktadır. Günümüzde farklı yapılarda karşılaşılan bu "canavar" imgesi, her ne kadar köklerini çeşitli mitolojik öykülerden ve/veya halk anlatılarından alsa bile, yapı itibari ile bu 
köklerinden oldukça farklıdırlar.

Sosyolojik düzlemde ele alınabilecek böylesi bir yorum, psikanalitik düzeyde de benzer bir tınıya sahiptir. Lacancı 'imkansız bakış'ı öyküde görselleşmiş olarak buluruz. Canavar, Dr. Frankenstein'ın eşiyle cinsel birliktelik anını karanlık bir köşeden izlerken, aslında kendi varlığının rahme düşüş anına tanıklık ediyor gibidir. Ancak o anda toplumsallığın metaforu gibi ele alınabilecek olan, birbiriyle uyumsuz parçalardan, kadavralardan bir araya getirilerek, birbirine dikilerek yaşam bulmuş bir ucube olduğunun farkına varır. Bu imkansız bakışta imlenen farkındalık anı, canavarı çılgına çevirir. Bu farkındalık anı, köklerinden koparımış olmanın bilincine varıp, gerçeklik ile kurgu arasındaki farkı, kendi bedeninde kavrayışa dönüştürmenin yakıcı anıdır. Ve doğa ikinci kez şiddetle tahrip edilir. Canavar, Baba'dan intikamını Anne'yi (kadını) öldürerek alır. Bu imge, Modern bilimin ve teknolojinin doğa üzerindeki zaferi gibidir. Mary Shelley'in bir kadın olarak bunu sezmiş olması ironik bir şekilde Lacancı 'kadın yoktur, dolayısıyla cinsel ilişki de yoktur' önermesinin anlamı üzerine, bilimsel ve teknolojik gelişmelerin yaratımı ele aldığı düşüncesine bizi götürmesi gayet anlaşıır görünüyor. Günümüzde bilim-kurgu türlerinde yapay zekanın sürekli bir kadın olarak tasvir edilmesi de garip bir şekilde Frankensein'ın canavarının öldürdüğü kadına/ doğaya yönelik bir özlemi barındırıyor diyebiliriz. Oedipus'un öyküsünün tersine çevrilip sonsuza kadar Baba/Kültür ile yaşamanın getirdiği çağdaş bir bunalım şeklinde de ifade etmek bir noktada mümkündür.

Moretti'ye göre (2005, s. 131-132) hem toplumsal hem de bireysel olarak bastırılanlar karşımıza canavar olarak çıkmaktadır. Örneğin hem filmlerde hem de romanlarda karşılaşılan Viktoryen Drakula'nın düşmanlarına yaptığı en büyük kötülük, 'iffetli kadınlarının haz düşkünü olmalarını sağlamak' olarak sunulmaktadır. Bu görüşe göre; Viktoryan dönemin cinsel baskılarının bir sonucu olarak canavarın en büyük gücü karşı koymanın güç olduğu bir cinsel çekime sahip olmasıdır. Bu düşünce, günümüzde form olarak değişiklik gösterse bile, giderek daha da popüler hale gelen, post-apokaliptik olarak adlandırılan 'kıyamet sonrası' bir dünyanın tasviri ile benzer baskılanmışlıkları izleyiciye sunabilmektedir. Yani günümüzde de baskılanan çoğu şey, sinema veya edebiyat gibi kültürel ürünlerde karşımıza canavarlar olarak çıkabilmektedir. Örneğin, Moretti'nin bu görüşlerini metaforik düzlemde benzer yaklaşımlarla kitlesel yok oluş anlatısının bir parçası olarak değerlendirebileceğimiz 
'zombi' filmlerinde de gözlemleyebilmemiz mümkündür. Bir başka ifadeyle küreselleşen dünyanın ve yeni dünya düzeninden ötürü tüm dünyanın bir tehlike içerisinde olduğuiletisi, zombi metaforu üzerinden sunulmaktadır. Şakrak' a göre (2018) yönetmenliği Yönetmenliği Marc Forster tarafından yapılan, 'World War Z' (2013) buna örnek olarak gösterilebilir. Filmde, Uzakdoğu'da başladığı düşünülen bir virüs salgınının insanların çok büyük bir bölümünü 'zombiye' dönüştürmesi, sağ kalanların ise hayatta kalmak için mücadele etmeye mahkûm olması konu edinilmektedir. Önceleri sınırlı bir alan içerisinde sunulan benzeri bir senaryo, küreselleşme kavramı ile ilişkilendirilerek tüm dünyanın içerisine dâhil edildiği bir yapıda öyküleştirilmiştir. Tehlikenin tüm insanlık için olduğu görüşü ön plana çıkarımaktadır.

Bastırılanın geri dönüşü konusu, Lacancı psikanalizin de temel meselelerinden birini oluşturur. Zizek, bu konuyu, "Yaşayan Ölülerin Dönüşü" filmi üzerinden değerlendirir. Ve bir 'ölü' neden geri döner şeklinde bir soru sorar. Cevabı Zizek yine kendisi verir. "Uygun bir şekilde gömülmediği için". Buradaki uygun bir şekilde gömülmeme düşüncesi, hem bireysel hem toplumsal düzeyde libidinal ekonominin tatmin edilmemesi ile ilişkilidir. Politikada vaadlerin gerçekleştirilmemesi, işçinin tatmin edici ücretlerini almaması vs. bir sürü örnekleme gösterilebilir. Edebi anlamda da Stephen King 'in kült romanlarından olan 'Hayvan Mezarlığı' burada anılmalıdır. Hatta bu roman, Zizek'in ifadesiyle; "yaşayan ölülerin dönüşü"nün nihai romansallaştırılışı sayılabilir. Romanda, Dr. Frenkenstein gibi bir doktor olan Lovis Creed'in öyküsünü okuruz. Louis ve ailesi kentin hengamesinden bunalmıs ve sakin bir kasabada konforlu bir eve taşınmışlardır. Ancak ev, sürekli kamyonların geçtiği anayola yakın bir yerdedir ve bir süre sonra evin kedisi Church bir kamyon kazasında ölür. Çocukları bu duruma çok üzülür ve Louis, kediyi komşularının hiç de salık vermediği bir yere gömer ve o akşam Church dirilip geri döner. Illerleyen günlerde Louis oğlu Gage'i de benzer bir kazadan dolayı gömmek zorunda kalır. Ancak onu da yine yasak bölgeye gömer ve o gece Gage de dirilip geri döner. Ancak Church de, Gage de içlerinde kötücül bir ruhla dönmüşlerdir. Dahası bir canavar olarak, yaşan ölü olarak geri dönmüşlerdir. Gage annesini öldürür. Lovis karısını da aynı yasak bölgeye gömer ve roman sona ererken, Lovis mutfakta kağıt oynayıp karısının dönüşünü beklemektedir.

Modern dönemde sıklıkla gündeme gelen korku ve kitlesel yok oluş filmlerinde 


\section{arts}

yer alan kötülük temsillerinin çeşitli modern toplum normlarına yönelik sert bir dönüşüm üzerinden kendisini sunduğu gözlemlenebilir. Bu anlatılarda kurgulanan gerilim ise genellikle toplumun muhafazakâr kurumları tarafından çözümlenir. Ayrıca bu tür yapımlarda toplum tarafından ötekileştirilen veya gizlenen yapı veya düşünceler kendilerini canavarlık üzerinden var ederler. Bu görüşü genel olarak bu tür yapımları tamamında gözlemleyebilmemiz mümkündür. Bunun sebebi ise modern kültürün kendini var edebilmesi için baskıladığı şiddet ve cinsellik gibi olguların canavarlık metaforu üzerinden izleyiciye sunulmasından kaynaklandığı düşünülmektedir. Klasikleşen pek çok kitlesel yok oluş filminde böylesine duygu ve dürtülerin hâkimiyetinde bir toplum varoluşunu sürdüremeyeceği görüşü izleyiciye sunulur ve muhafazakâr toplum düzenini sağlayan kurum, kuruluş veya kişilerin müdahaleleri ile yeniden bir toplum düzeni inşa edilir ve 'güven' ortamı yeniden sağlanır. Her ne kadar pek çok özeliği ile çağdaş filmlerde, klasik filmlerdekine benzer bir yapıyı gözlemleyebilsek bile toplumun moderniteye yönelen bir birliktelik içinde yeninden inşa edilen bir yapıda kurgulanması ile daha az karşılaşmaktayız (Şakrak, 2018).

Günümüzde sinema filmlerinde karşılaşılan canavar imgesi ile geçmiş dönemin hatta mitolojinin güçlü bir ilişkisi olduğunu söyleyebilsek bile aralarında nitelik bakımından büyük farklar olduğunu söyleyebiliriz. Örneğin; ölülerin dirilmesi düşüncesi, George A. Romero'nun "Yaşayan Ölüler" filmini yapmasından öncesinde de popüler olsa da, zombiler ancak Haiti mitolojisinde bulunan folklorik bir unsur olarak algılanmaktaydı. Güncel sinema filmlerinde ele alınış biçimlerinin ötesinde zombiler çok az kimsenin bilgisinin olduğu, kötü niyetli kimselerin uygulamaları ile ortaya çıkabilecek bir "voodoo" büyüsü uygulaması olarak bilinmekteydi. Bir başka ifadeyle Batı Hint milletleri için zombiler modern dünyanın kurum ve kuruluşlarını, toplumları yok etmekten başka amacı olmayan akılsız yaratıklar olmanın ötesinde anlam taşımaktadırlar. Onlar hem üretildikleri toplumun gelenek ve göreneklerini hem de inançlarını somutlaştıran etnografik ve antropolojik yaratıklardır. Bir başka ifadeyle kültürel kodların yeniden veya aynen yorumlanmasından kaynaklanan inanışlar korku hikayelerinde yer alırken günümüzde bu fikir kendisini toplumsal çöküşün ve yeni bir toplum ve bireyin inşasının gerekliliği ile öne çıkarmaktadır (Thomas, 2010). 


\section{Yüzyıl Sinemasında Kıyamet Sonrası Dünya}

İnsan türü, tüm tarihi boyunca olgulardan önce olayların, 'neden' olduğu konusunda açıklamalara ve/veya bir 'mutlak neden'e intiyaç duymuştur. Bir olayın nedenini bilmemek bizim türümüz için kabul edilebilir değildir. Böylece insanlar karşılaştıkları zorluklarla başa çıkmak ve bilinmeyenleri açıklamaya çalışmak için mitsel anlatılar geliştirmiş, zihinsel gelişiminin bir noktasından itibaren de varoluşa ve ölüme, ölüm sonrasına ilişkin felsefeler ve dinsel söylenceler ortaya koymuştur. Bu açıdan bakıldığında 'Apocalypse' sözcüğünün (Yunanca: apokalypsis) vahiy veya açıklanma anlamlarına gelmesi daha ilginç bir hal almaktadır (Wojcik, 1997). Yaşamın parıldamaya başlamasından önce ne olduğunu ve yaşamın son bulmasından sonra ne olacağını kimse bilmediğinden dolayı farklı kültürler farklı cevaplar yaratmıştır. Bu cevapların çoğunda ise 'canavar' metaforları yer almaktadır. "Bulutlardaki kanatlı meleklerden aşağıdaki şeytanlara kadar, dini görüş fantastik varlıklarla dolu bir bloktur" (Landis, 2011).

Dünyanın sonu, dolayısıyla; yaşamın sonu düşüncesi, her kültürün, inancın ve düşünüşün temel konularından biri olmuş, çeşitli açılardan yorumlanmış, insan türünün sürekli ilgisinin mazharı olmuştur. Kadim antik-pagan kültürlerin mitolojik söylemlerinden, dinsel örgütlenmelerin nihai şeklini aldığı modern zamanlara kadar tüm toplumlar, bu 'son' düşüncesiyle baş edebilmek için, gökyüzü cennetlerinin ışıltılı tasvirlerini yapmış, hatta birçok kültürde betimlenen ulvi cennetlere gitmek için yaşamın sona erişi mutluluk içinde kabul edilmiştir. Örneğin İskandinav mitolojisinde Valhalla'yagidipOdin'insofrasındayerbulmak, savaşçılariçinentemelmotivasyondu. Semavi dinlerdeki şehitlik vurgusu da tümüyle bu yönlüdür. Yine aynı anlatılarda, bir meta-anlatı olarak "büyük kıyamet ve sonrası", tanrısal bir müdahale olarak tüm yaşamı sonlandıracak bir iradeyi düşünceye kazımıştır. Ancak yakın döneme kadar bu anlatılar ilahi bir müdahale ile dünyanın yok oluşu fikrini vurgularken, 20. yy'ın özellikle ikinci yarısından itibaren nedeni tanrısal gerekçelere dayanmayan bir yok oluş fikri, kendine yer bulmaya başlamış ve günümüzde neredeyse Tannı kaynaklı kıyamet düşüncesi kadar popüler hale gelmiştir. Özellikle nükleer silahların keşfi ve kullanımı kitlesel yok oluş fikrinin insanların elinden gerçekleştirilebileceği gibi bir öngörüyü güçlendirmiş ve bu görüşün popülerliğine katkı sağlamıştır (Wojcik, 1997).

Kimilerine göre; homo-religious, olarak ifade edilen insan, kırılgan yapısından 
ve sınırlı yaşamından dolayı sürekli, Tanrısal bir çözüm arama (divine comfort) durumundadır (Bilici, 2007). Bu gerekçede; yaşamın yıkıcılığından, insan türünün yarattığı yıkımlardan kurtulabilmek için, eski, güzel zamanlara dönme arzusu yatmaktadır. Dahası bu anlatılarda, insan soyunun tüm çabasının Aden bahçelerine, her şeyin barış ve sonsuz bir huzur içinde olduğu cennete tekrar dönebilmesinde özetlenmesidir. Aydınlanma çağının zirve noktası olan Fransız devriminden sonra gelişen terör döneminde, Romantiklerin dillendirdiği 'Altın Çağ' özlemi, geçmişe yönelik özlemlerin de bir ifadesi olarak ele alınabilir. Thomas Moor'un "Ütopya"sı, Campanella'nın "Güneş Ülkesi" aynı, mitik, teolojik bir dileği de içeren özlemi içinde barındııır.

20. yüzyılda özellikle 1. ve 2. Dünya Savaşlarının sonuçlarında ortaya çıkan insanlık dramları, sürekli bir tehdit olarak sunulan veya insanların bilinçaltlarında yer edinen nükleer savaş tehdidi, soykıımlar ve türleri yok etmeye yönelen çeşitli potansiyel tehditler, Modernite'nin vaat ettiklerinin ve bu vaatlerin toplumsal sonuçlarının sorgulanmasına neden olmuştur (Bilici, 2007, s. 150). Bu görüşün en önemli gerekçelerinden birisi aslında sanayi devrimi ve buna paralel olarak ilerleyişini sürdüren aydınlanma hareketi olarak düşünülebilir. Önce Avrupa' da etkisini gösteren aydınlanma düşüncesi, daha sonra bütün dünyada bir etki bırakmıştır. Aydınlanmanın getirdiği sanayileşme hamleleri ise daha önce kırsal alanda görece daha küçük topluluklar halinde yaşayan insanların şehirlere göç etmesine sebep olmuş; bu durum ise toplumsal yapıda büyük değişikliklerin yaşanmasına neden olmuştur. Şehir yaşantısı insanların o döneme kadar alıştıkları iletişim biçimleri üzerinde de büyük değişikliklere sebep olmuştur. Her ne kadar insanın şehirlerde büyük kitleler halinde bir arada yaşamasının çeşitli avantajları olsa bile; bu durum birçok olumsuzluğu da beraberinde getirmiştir. Bu olumsuzlukların başında da; insanların fantazmalarındaki değişim ve dönüşüm olmuştur demek her halde abartı sayılmayacaktır.

Film endüstrisi için 2. Dünya Savaşından sonraki en önemli tehdit, savaş bittikten kısa bir süre sonra birçok Amerikan evinin erişebileceği ticari televizyondu. İlk defa, insanlar evlerinde hareketli görüntüler izleyebiliyordu ve bu görüntüler sıklıkla kaydedilmekten çok canlıydı. Savaştan sonra yaşanan konut kıtlığı ve federal otoyol sisteminin tanıtılması, birçok Amerikalı'nın şehir merkezindeki görkemli eski tiyatrolardan oldukça uzak olan yeni banliyölere taşınmasına neden oldu. Film 
endüstrisi, televizyonla rekabet etme çabalarında içerik ve formattaki değişikliklere cevap verdi. Film temaları, o sırada televizyondan kaçınan, artan miktarda cinsel içerik ve şiddete sahipti. Bu temalar, evde yeni bir televizyonun varlığına bakmaksızın, hafta sonları dışarı çıkmak isteyen genç izleyiciler arasında da popülerdi (Paxson, 2018). Ancak; hareketli imgenin, politik, ideolojik veya didaktik gücü, daha 1900'lü yılların başında fark edilmişti. 2. Dünya Savaşından sonraki çift kutuplu dünyada da, Kapitalist Modernitenin Demir Perde ülkelerine karşı, reel politikanın dışında, sinema aracılığıyla küresel çapta bir büyük düşman öteki imgesi yaratması bu noktada anlaşıır oluyor. Dikkat edilirse; sinemanın son 40-50 ylında sinematografik imge anlamında düşman öteki, film endüstrisinin her türdeki kategorilerine (bilim-kurgu, korku, fantastik) sirayet etmiştir.

Kitlesel yok oluşun anlatıldığı bu tarz bir kıyametin anlatıldığı bir yapımla, fantastik veya mimetik tür arasında temel bir takım farklar bulunmaktadır. Örneğin edebiyatta mimetik kavramı bize gerçek dünya ve onun tasvirleri ile ilişkili bir düzeni çağrıştır, fantastik edebiyat ise gerçek dünya ile yakından ilişkili olsa bile, gerçek dünya üzerinde doğrudan bir etkisi olmayan yeni bir alanı çağrıştııı. Ancak kıyamet sonrası dünya tasvirlerinde ise yaratılan dünya her ne kadar yeni bile olsa gerçek dünya ile büyük oranda ilişkilidir (Ketterer 1974). Bir başka ifadeyle 'kıyamette' yıkılan ve 'kıyamet sonrası' dönemde tarif edilen yer yeni bir alan değildir: temel özellikleri ile günümüz dünyasının bir yansımasıdır. Bu yıkım dünyasına yazar veya senarist tarafından yerleştirilmeyen, adlandırılmayan, söylenmeyen her şey, okuyucunun veya izleyicinin aklında bir tür ontolojik boşluk olarak kalır. Var olduğunu biliyor olabilirler, ancak neye benzediği ile ilgili bilgileri güncel olmayabilir. Bu düşünceden hareketle bu yeni tasvirin günümüz insanı için oldukça doğal bir alan olduğunu, dünya ansiklopedimizin bir parçası veya sakini olabileceğimiz bir alan olduğunu söylememiz yanlıs olmayacaktır (Skult, 2015).

Kıyamet sonrası dünya tasvirlerinin anlatılığı bir kurguda genellikle yaşanan kıyamet gerçekleşmekte olan bir olgu olarak değil geçmişte yaşanmış ve sağ kalanların mevcut duruma adapte olduğu veya olmaya çalıştığı bir öykü içerisinde anlatıır. Buna durumdan hareketle kıyamet öncesi insanın, olgunlaşmamış (mitik) insan olduğunu söyleyebiliriz. Metaforik düzlemde henüz çocukluk dönemini yaşayan insanlık kendi kendini yok ederek ergenliğe ulaşmak için ihtiyacı olan temel 
fiziki ve ruhsal yetilere sahip olacaktır. Bu açıdan bakıldığında kıyamet sonrası dünya tasvirlerinde yaşanan yıkım araçsallaştıılarak kurulacak yeni düzenin bir başlangıcı olarak kullanılır (Boz ve Takımcı, 2019, s. 38).

Çağımızın, kıyamet sonrası filmlerde yer alan distopik öğeler bir seküler nitelikler taşımaktadır. Binlerce yıllık dini kıyametin imgesi bu filmler aracılığı ile değişiklik göstermekte ve yeni bir anlama evrilmektedir. Bu tür yapımlar genel olarak geniş toplumların yok oluşu ve yeni küçük komunitelerin inşa edilmesi, yalnızlık deneyimleri, düzenin bozulması, kimlik krizleri veya insanın anlama yetisinin üzerinde bir gerçeklikle karşılaşma gibi konular üzerine odaklanırlar (Voigts ve Boller, 2015).

\section{Bird Box}

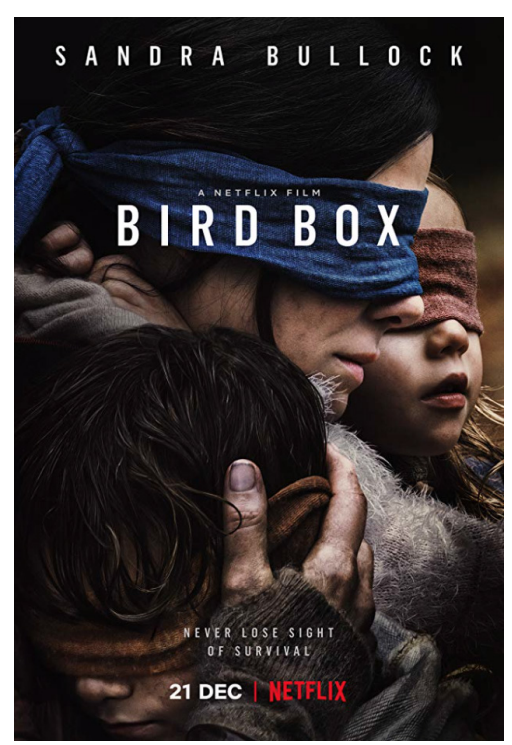

Görsel 1 Bird Box Filmi Afişi (2018)

Bird Box filmi, küresel çapta bir 'yok oluşun' yaşanmasına neden olan, ancak tam olarak ne olduğu belli olmayan bir 'canavardan' kaçmaya çalışan bir grup insanın hikayesi üzerine odaklanmaktadır. Ancak filmdeki canavar imgesi, sadece ne olduğu belli olmayan, anlaşılmayan bir şekilsizliği-biçimsizliği imlemiyor. Bu canavar insanların görme duyularına etki etmekte ve dış dünyada görüldüklerinde, görenin kendisini soğukkanlılıkla öldürmesine neden olmaktadır. Filmin canavara ilişkin dehşetengiz sahnelerinden birinde, biçimsiz-şekilsiz ve -hali hazırda- herkes tarafından görünmez bu kıyametvari tehlikenin, görme duyusuna etki ettiği insanların kiminde, eski yaşantılarını anımsatır bir şekilde, bir anne, baba, kardeş, arkadaş gibi 
göründüğünü veya görenlerce öyle tanımlandığını fark ederiz. Örneğin filmde ana kahramanımız Malorie olaylar patlak verip canavarlar ortaya çıktığında sığınacak bir yer arar. Araçlarının takla atmasından sonra yanda bulunan evin sahibi başka bir kadın onu kurtarmak için sokağa çıkar ancak filmin canavarlarından birisini görür ve ona "Anne? Lütfen gitme" dedikten sonra yanan bir aracın içine oturur. Filmin bir diğer ilginç noktasını, bu görünmez canavarın körlere ve akıl hastalarına herhangi bir zarar vermediği oluşturmaktadır. Sanki tüm insanlık yok olsa, sadece körler ve akıl hastaları kalacakmış gibi bir sınır- durumla karşılaşırız.Birdbox'ın canavarlarının muğlak formları ve niteliksel özellikleri ile korku temasının bir unsuru olarak işlev gördüğünü söylememiz mümkündür. Ancak bu tema filmin ikinci yarsıyla birlikte büyük bir değişime uğramaktadır. Yaşanan kaostan kurtulan insanlar artık yaşanan kıyamete büyük ölçüde adapte olabilmiş olsa da Gary adında başka kurtulanı eve kabul etmelerinden sonra daha önce bildikleri canavardan daha tehlikeli bir korku unsuru ile bir araya gelmişlerdir. Filmde akıl hastanesinden kaçanlar olduğundan bahsedilir ve bu akıl hastalarının, göz bağlarına ihtiyaçları olmadıklarını, gülümsediklerini ve diğer insanların canavarlara bakmalarını sağladıklarını öğreniriz. Bir diğer ilginç noktayı ise, akıl hastalarının bu canavar tarafından tehlikeli birer varlıklara dönüştürülmesidir. Akıl hastaları canavarı görürler ve onun yıkıcı amacını paylaşılar. Hatta kendilerini, canavarın havarileri gibi düşünüp, yok oluşun gerçekleştiricilerinden biri olma şeklinde konumlandıırlar. Akıl hastalarının yok oluşu gerçekleştirmek gibi bir misyonları bulunmaktadır.

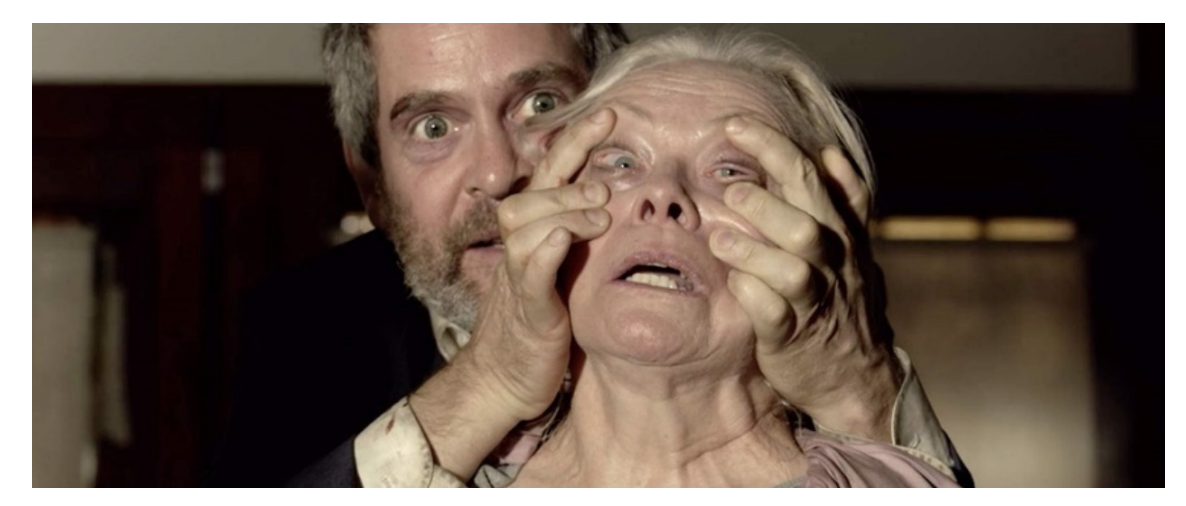

Görsel 2 Akıl hastaları insanların canavarları görmesini istemektedir, Bird Box (2018)

Kıyamet senaryosunun başlangıcından önce Malorie adlı ana karakter, dışarıda yaşananlardan kaçınmakiçin bir eve sığınmıştır. Diğer dokuz karakterle birlikte 


\section{arts}

bir arada bu evde bir süre dışarıda nelerin yaşandığını anlamlandırmaya çalışılar. İçeride bulunan bu dokuz karakterin sayısının filmin süresine göre fazla olmasından dolayı yüzeysel olarak işlendiği, derinlikli karakter analizlerinin yapılmadığını söyleyebiliriz. Her ne kadar filmde bu karakterler arasında insani ilişkiler kurulsa bile bireysel niteliklerinden çok az bahsedilmiş ve film ilerledikçe sığınak olarak kullanılan bu evin nüfusu çeşitli karakterlerin ölümüyle giderek azalmıştır.

Hayatta kalma, kaçınılmaz kıyamet karşısında bu insan güçsüzlüğü görüşüne bir istisnadır. Çaresizlik duygularından ziyade, hayatta kalanlar, belki de felaketleri takiben dünyaya ait yenilenme beklentilerini barındıran, beklenen felaketlere dayanmaya hazırlanırken, kişisel kontrol ve kişisel kurtuluş duygusu ararlar. Bununla birlikte, hayatta kalanlar, seküler kıyamet senaryosu ile yaşama beklentilerikonusunda atipiktir. Dünyadaki yenilenmenin efsanevi bileşeninden ve ilahi kontrolüne olan inancından yoksun bırakıldığında, dünyanın değiştirilemez yıkımı hakkındaki fikirler, sonuçta bir nihilist kadercilik biçimi olarak ifade edilebilir (Wojcik, 1997).

Filmin akışı içerisinde insanlığın büyük bir bölümü yok olur, bilinen toplum düzeni yıkılır ve insanların göz bağları ile dolaşabilecekleri yeni bir toplumsal düzen kurulur. Filmin ana kahramanları olan anne ve iki çocuk bu süreçte çeşitli zorluklarla beş yıl hayatlarını sürdürebilmiştir ve bir marketten buldukları telsizden gelen bir çağıının kaynağını bulmaya çalışmaktadırlar. Bu çağıda anne ve iki çocuğa seslenen 'Rick' adlı karakter her ne kadar güvenli bir sığınağın olduğunu söylese bile, kahramanlarımızın buraya ulaşabilmesi için uzun ve tehlikeli bir sal yolculuğunu yapması gerekmektedir. Filmin genel olarak iki bölüme ayrıldığını söyleyebiliriz. İlk bölüm, yaşanan kıyametin ortaya çıkısının anlatıldığı süreci görmemize olanak sağlarken ikinci bölüm, olayların yaşanmasından beş yıl sonrası yapılan iki günlük tehlikeli bir sandal yolculuğunu seyirciye sunmaktadır. Filmin kurgusu, çeşitli geçmişe dönüşlerle (flash-back) olayların başlangıcını ve gelişimini seyirciye gösterecek şekilde yapılsa da ana hikâyenin bu sal yolculuğuna odaklanıldığını söylemek mümkündür. Film, ana kahramanlarımızın çeşitli zorlukları aştıktan sonra Rick'in vadettiği, aslında bir görme engelliler okulu olan binaya, güvenli sığınağa ulaşmasının ardından sonra ermektedir.

21. yılla birlikte iletişim alanında büyük gelişmeler yaşanmış; internet, televizyon 
gibi geniş kitlelere hitap eden iletişim araçları her eve, her cebe girmiştir. Ancak iletişim olanaklarının bu kadar geniş olması kimilerine göre bireysel iletişimi engellemektedir. Insanlar internet gibi ortamlarda sanal kimlikleri ile iletişim kurmaktadırlar. Bu durumda bireyler veya topluluklar başka bireylerle veya topluluklarla etkileşime geçseler bile iletişime geçememektedirler (Castells, 2013). Bu durum tam da romantiklerin 18. yy'dan beridir karşı durdukları duruma işaret etmektedir. Frankestein romanında olduğu gibi teknolojik ve bilimsel gelişme insanların hayatlarını 'kolaylaştırsa' veya romandaki gibi 'ölümsüzlüğünü' sağlasa bile yeni bir canavarın ortaya çıkmasına neden olmaktadır. Bu özelliğin genel olarak kıyamet sonrası sinemanın temel konusu olduğu anlaşılmaktadır. Bird Box filminde de benzeri bir yapının kurgulandığı anlaşılmaktadır. Filmin ilk sahnesinde ana kahramanımız Malorie'nin yaptığı resim, televizyonda gösterilen şiddet olayları seyirciyi bu noktaya yönlendirmektedir.

Kitle iletişimi ve araçları denilen şeyin öncelediği konjontür, genellikle nitelikten önce, niceliksel olarak ulaşabildiği geniş sahaya ilişkindir. Bu yüzden dikkat edilirse; İstatistik dediğimizde de, sadece nitelik belirtmeyen sayılardan söz etmiş oluruz. Daha doğrusu; sayısallaştırmaktan dem vurulmuş olur. Buna karşın, kişilerarası iletişimde ise bunun tam tersini gözlemleyebilmemiz mümkündür. 20 ve 21 . yüzyılda karşılaştığımız kitle iletişimi, kişisel iletişimden özellikle daha fazla insana ulaşabilme Özelliği ile ayrılmaktadır (Paxson, 2018). Günümüzde insan iletişim alanında yaşanan gelişmeler, kalabalık şehir yaşantısı çeşitli duyu ve duygulara yönelik işlerin çok daha fazla karşılaşılmasına neden olmaktadır. Dolayısıyla sinema filmlerinde de benzer duyuların öneminin vurgulandığı yapımlarla karşılaşabilmekteyiz. Özellikle son dönemde korku türünde ekranlara gelen sinema filmlerinde yalnızkalmak, görmemek ve duymamak gibi temel bazı belirleyicilerin; hayatta kalmaya yardım eden unsurlar olarak izleyiciye sunulduğu gözlemlenebilmektedir. Örneğin John Krasinski'nin "Sessiz Bir Yer" (A Silent Place) adlı filmi Birdbox gibi kıyamet sonrası bir dünyada bir ailenin konuşmak gibi temel bir becerisini, iletişim olanaklarının sınırlandırımasını konu edinmektedir. Görme ve konuşma gibi iki temel niteliğin yokluğunda yaşamı konu alan bu iki film bu özellikleri ile her ne kadar benzer görünse bile farklı anlatım olanaklarını kullandıkları ayrışmaktadırlar. Benzer bir şekilde 'The Happening' filminde de kimliklerini veya formlarını bilemediğimiz 'canavarlar' kalabalık gruplar halinde bir arada olan insanları öldürmektedir. 


\section{arts}
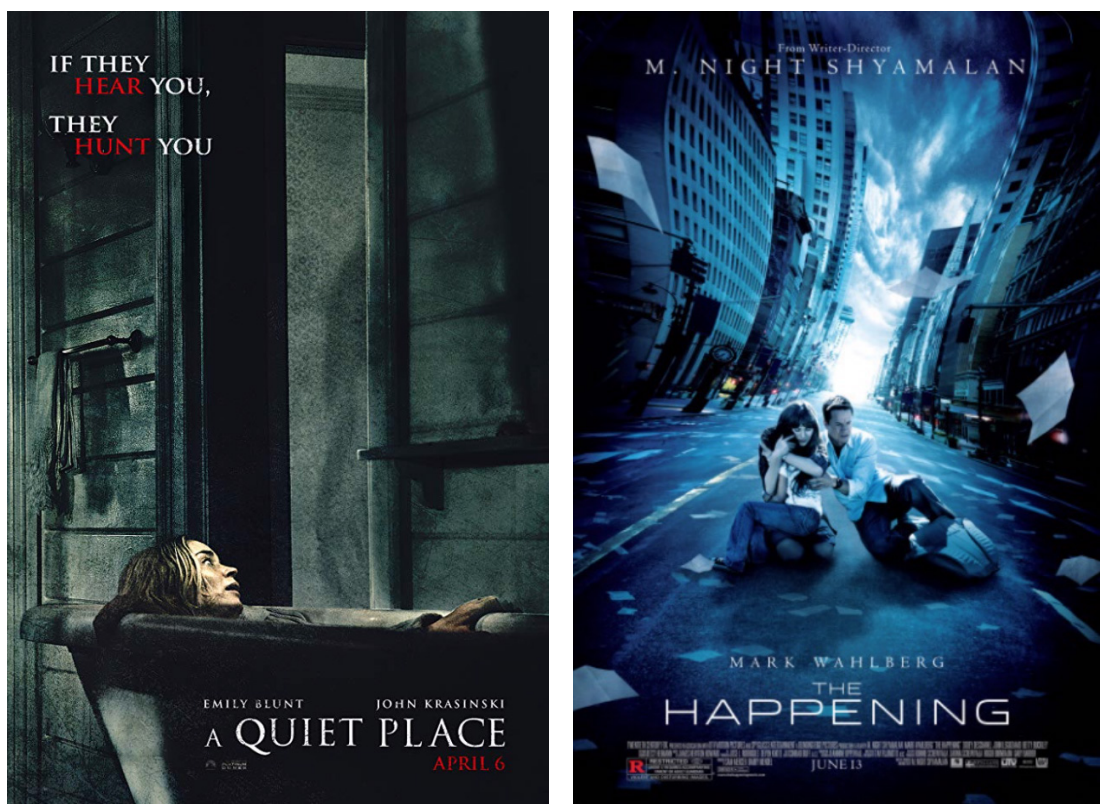

Görsel 3 Sessiz Bir Yer (A Quiet Place) Filmi Afişi (2018) ve Mistik Olay

(The Happening) Filmi Afişi (2003).

Günümüzde yukarıda bahsedilen ve bu filmlere benzer pek çok filmin kahramanı ancak belli başı eylemler sayesinde hayatta kalabilmektedir. Son yılların korku ve gerilim türündeki filmlerinin pek çoğunda işlenen potansiyel tehlikeleri görmemek, duymamak, kalabalık topluluklar kurmamak hayatta kalanların temel nitelikleri olarak sunulmaktadır. Geçmişte yapılmış benzer türlerdeki yapımlara bakıldığında ise genellikle tehlikenin kaynağı kısaca açıklanır veya oluşan tehlikenin geçmişi, eylemlerinin motivasyon kaynağı izleyiciye sunulabilirdi. 21. yy sinemasının canavarlarının çoğunda ise muğlaklık hakimdir. Bu film açısından izleyicinin gerilimin sürekli diri tutuımasında bir araç olarak kullanılabildiği gibi, modern insanın korkulanın kaynağını yani iletişim kuramaması üzerinden izleyiciye sunması açısından da anlamlı görülebilir.

Birdbox'ın canavarları da ancak aydınlık ve açık alanda etkili olabilen muğlak bir forma sahip yaratıklardır. Insanlar ise ancak yiyecek gibi temel gereksinimlerini karşılamak için gözbağları ile dış dünyaya adım atmaya cesaret edebilecek durumdadır. Ayrıca yaşanan bu kıyametten önce veya sonrasında akıl sağlığını kaybeden insanların da bu canavarların birer aracı veya yansıması olarak kullanıldığını söyleyebiliriz. İnsanların akıl sağlığını kaybetmesi ve canavarlaşmaları ise genel olarak korku filmlerinde sıklıkla kullanılan bir klişedir. 


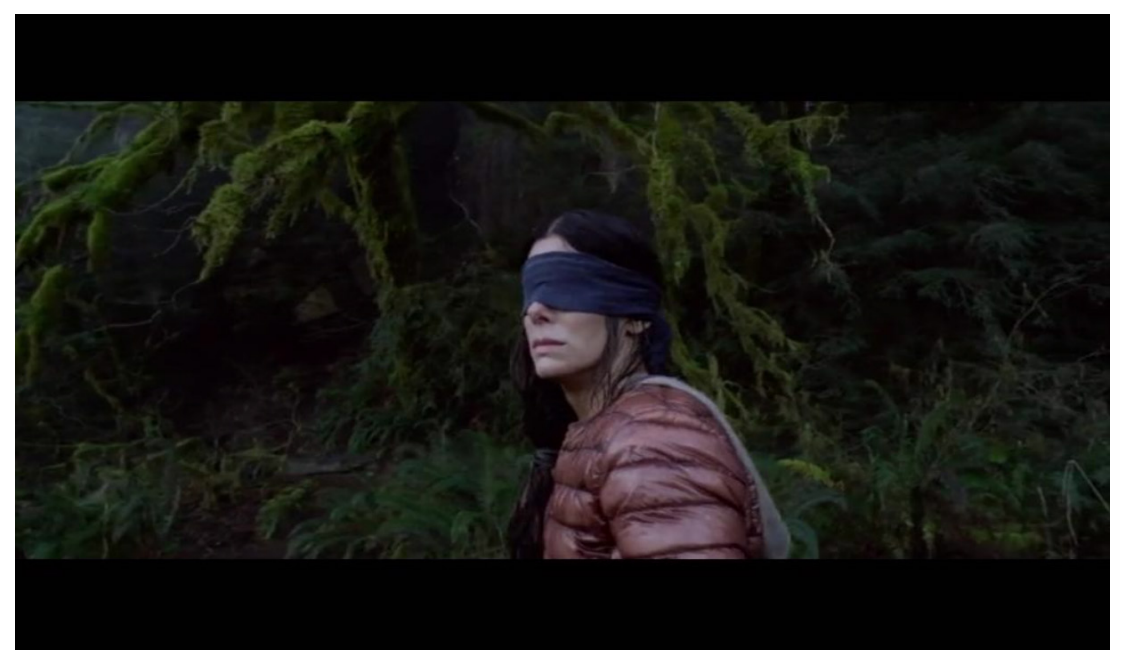

Görsel 4 Malorie'nin ormanda yol bulmaya çalıştığı sahne, Bird Box (2018)

Bird Box filmi de iletişim çağında bireyin yalnızlığın gözler önüne sermektedir. Günümüzde iletişimin büyük bir bölümünün görme duyusu üzerine kurgulandığı düşünüldüğünde veya bir başka ifadeyle görmeye diğer tüm duyulardan fazla görev düştüğü çağımızda; filmin canavarların görme yetisine sahip insanları hedefine alması tesadüfi değildir. Toplumsal iletişimin büyük bölümünün görüntüler üzerinden sağlandığı çağımızda; görememek en büyük korkulardan birisi olarak sunulmuştur. Bir başka ifadeyle günümüzde her zamankinden daha fazla imajın üretildiği ve tüketildiği bir yapının egemen olduğu söylenebilir. Bu açıdan bakıldığında günümüz dünyasının imajlar dünyası olduğunu söylememiz yanlış olmayacaktır. Böyle bir ortamda bireyin kendisini var etmek için bir kolektiviteye entegre olma çabası onun sosyalleşebilme beceri ve intiyaçları açısından eskiye göre çok daha önemli bir hal almıştır. Bireyin topluma karşı yabancılaşmasını ve kaygılarını temelinde konu edinen post apokaliptik sinema, post-modern bakışla modern toplumun yıkılışını ve modernitenin kurum ve kuruluşlarının yokluğunda, belirsizliğinde hayatta kalma ve karar verme yükümlülüklerini sorgulamaktadır.

Günümüz sinemasında 'canavar' kavramının kullanımında giderek daha muğlak bir anlatımın tercih edildiği gözlemlenebilmektedir. Yukarıda belirtilen filmlerde insanların kitleler halinde yok oluşu ortak bir temada anlatılırken, buna neden olan şeyler farklılık göstermektedir. Ancak canavarların hiç birisinin bir bedeni, formu, geçmişi ve geleceği ile ilgili bir gösterge bulunmamaktadır. Bu tercih izleyici için bir muğlaklığı doğurduğu gibi korkunun etkisini artırabilmektedir. Birdbox filminde 
de yer alan ana karakterin çocuklarını neden kaynaklandığını bilmediğimiz tehditte karşı koruması içgüdüsü üzerinden sunulan gerilim sık sık hızlı geri dönüşlerle (flashback) canlı tutulmaya çalışıımışır.

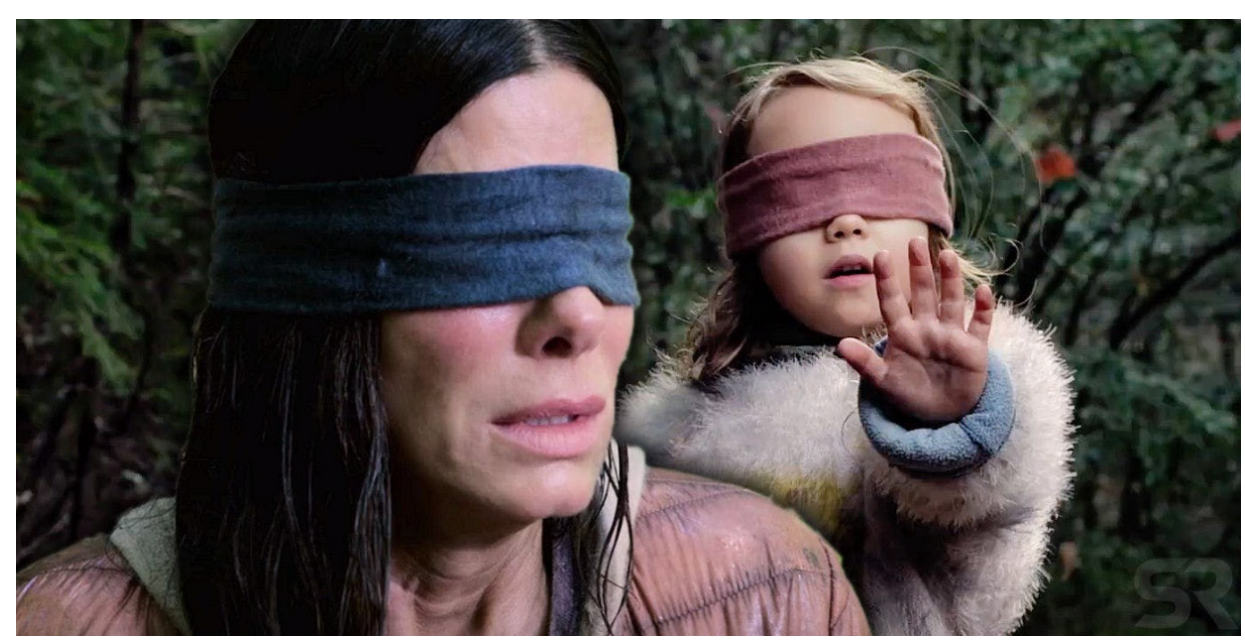

Görsel 5 Malorie ve kızının ormanda yol bulmaya çalıştıkları sahne, Bird Box (2018)

Bu açından bakıldığında; bu makalenin de konusu olan 'Bird Box' filmi, modern çağın bütün imkanlarını yaşayan bireylerin hayatlarındaki radikal bir değişikliğe işaret etmektedir. Filmin açılışında, insanların görme duyusuna yönelik gelişen ve ne olduğuna dair hiçbir fikrimizin olmadığı ölümcül tehdit, başlangıçta bireylere yönelikmiş gibi görülürken, filmin akışı içerisinde bunun küresel çapta bir tehdit olduğu anlaşılır. Film, Paxon'un da belirtmiş olduğu gibi; her düzeydeki kitlesel iletişimin (görüntüsel, gösteri, bakış, ayna vs. ) geldiği noktayı, bir yok-oluş fantazması içinde ele alıyor. Seyirci de, film boyunca tam da bu yok oluş fantazması içindeki çeşitli göstergelerle, aynı fantamagoria'ya dahil edilmiş olur.

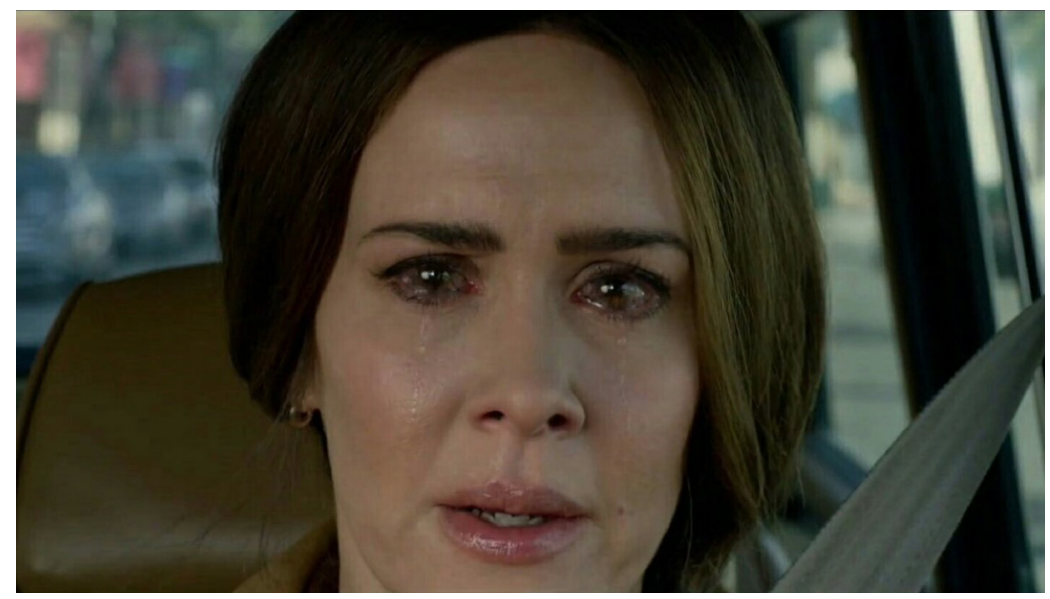

Görsel 6 Jessica yaratıklardan birisini gördüğü sahne, Bird Box (2018) 
Bird Box filmi, aslında bazı açılardan, kadim mitsel-teolojik öyküleri de anımsatan özelliklere sahiptir. Filmde, insanlığın teknolojik açıdan geldiği düzey, enformasyonların aktarımasındaki hız, kitle iletişiminin aslında bir iletişimsizliği beraberinde getirişi (dilin bu anlamda bir anlamsızlıkların aktarımasına dönüşmesi, ya da şöyle diyelim; dilin anlamlı iletişimi mümkün kılamayacak kadar yavanlaşması) insanlığı cezalandırıması gereken bir suçu işlediği ve kitlesel bir yok oluşu hak ettiği düşüncesiyle birlikte işlenir sanki. Cezalandırıcı güçlerin (canavarın) harekete geçtiği ilkzamanlardan, insanlığın büyük bölümünün yok olduğu (cezalandırıldığı) zamanlara denk düşen ve sanki bir mucizeymiş gibi beliren Rick'i, mitsel-dinsel anlatılardaki güvenli toprakları vaat eden bir 'haberci' olarak tanımlamamız mümkündür. Joseph Campell'ın, "Kahramanın Sonsuz Yolculuğu" nda belirttiği gibi; "Habercinin (Rick) haberi (güvenli bir yerin olduğuna ilişkin haber), yaşamak ve yaşamın daha ileri bir anında ölmek olabilir. Önemli bir tarihsel olaya çağı gibi görünebilir. Ya da bir dinsel aydınlanmanın şafağını belirtebilir (Görme engelliler okulu, neredeyse bir manastırı anımsatır). Kitlesel yok oluşla birlikte; "Alışımışın yaşam ufku genişlemiştir; eski kavramlar, idealler ve duygusal kalıplar artık yetmez; bir eşiği aşma zamanı gelmiştir" (Campbell, 2017, s. 55). Filmdeki iki günlük zorlu sal yolculuğu bu eşiği aşma zamanını bu açıdan imler. Daha ilginç olan, güvenli yer denilen bölgenin eski bir görme engelli okulu oluşu ile ilgili imlenen dinsel öyküdür. Adem ve Havva yasak elmayı yediklerinde, gözleri açılır. Görmeye başlarlar. Bu onların helakı olacaktır. Görme engelliler okulu bu anlamda Aden'de, Adem ve Havva'nın yasağı çiğnemeden önceki durumunu çağrıştırıyor gibidir. Bu Campbell'in de bahsettiği kahramanın yola ilk çıktığı nokłaya geri dönmesine işaret etmekte gibi gözükmektedir. BirdBox filmi için bu kahraman Malorie ve çocuklar gibi görünse bile aslında insanoğludur demek daha doğru olacaktır.

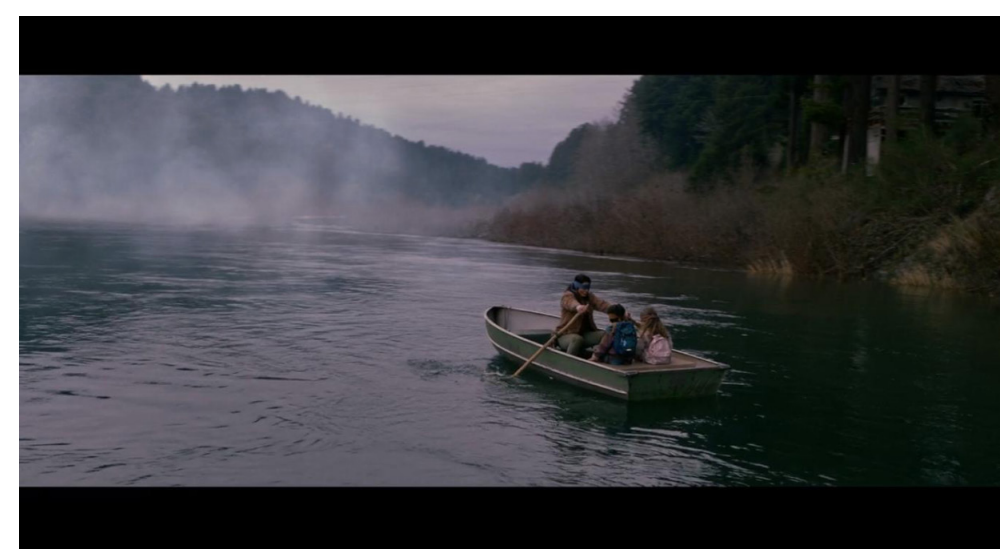

Görsel 7 Gözler bağlı yapılan sandal yolculuğu, BirdBox (2018) 


\section{arts $=$}

\section{SONUÇ}

Son yllarda korku, gerilim ve bilim-kurgu sineması türlerinin kesişim noktasında bulunan ve kıyamet sonrası insan topluluklarının yaşamlarına odaklanan filmlerin oldukça popüler olduğu gözlemlenmektedir. Anlatılan öykülerin belli başlı özelikleri ile ortaklaşıı̆ı̆, özellikle ilahi bir kıyamet düşüncesi veya anlatısı yerine; yeni ve çoğunlukla insan kaynaklı bir kıyamet düşüncesinin popülerleştiği görülmektedir. Kıyamet sonrası dünya tasvirlerinin seküler yok oluş öyküleri üzerine odaklanmalarının nedenini, bir açıdan; 20. yüzyılda yaşanan 1. ve 2. Dünya savaşları ile nükleer felaketlerin (Hiroşima, Nagazaki, Çernobil gibi), insanın dünya ile birlikte kendi türünün de sonunu getirebileceğine ilişkin idrakine bağlayabiliriz.

Yaşanan büyük kaostan kurtulan insanlar için ise, yeni bir toplumsal düzenin kurulması gerekliliği bu filmlerde anlatılan bir diğer önemli noktadır. Modern çağın imkanlarından ayrlmakzorundakalaninsanlar, yenibirhayatkurmakdurumundadıllar. Ancak bunun için, hakim toplumsal üst-yapı kurumlarının yokluğundan dolayı, kendi kararlarını almak, eyleme geçmek gibi bir takım zorunlulukları karşılamalıdırlar. Böylesi bir durum, bir ölçüde insanlığın köklerine dönüşü gibi düşünülebilir. İster dini anlatılarda yer alan öykülerde ister tarih kitaplarındaki bilgilerle ilişkili olduğunu düşünelim, bu tür filmlerde insanlığın sürekli olarak doğaya (ilahi Cennet'e) geri dönmesi gerekliliği vurgulanmaktadır. Benzer pek çok özelliği ile Birdbox filmi de, kıyamet senaryolarının işlendiği filmlere benzerliği nedeniyle, bu tür yapımların incelenmesi açısından iyi bir örnek olduğu söylenebilir. Modern çağın insanlara vaatleri bu tür filmler aracilığı ile sorgulanmakta ve sonuçta köklere yeniden dönüş gibi bir önerinin sunulduğu belirtilebilir.

Bird Box gibi pek çok benzer filmde bastırlanların karşımıza canavar olarak çıktığı anlaşılmaktadır. Günümüz kıyamet filmlerinde ise bu durum kitlesel korkular üzerinden kendisini sunduğu için toplumların baskıladıkları toplumsal canavarlar olarak sunulmaktadır. Kabul edilen düzen, sonuçta (tıpkı kapitalist yapıda Amerika'ya atıfta bulunan tüketim toplumunun zombilerle ilişkilendirilmesinde olduğu gibi) güç sahibi toplumsal sınııın düşünceleri açısından ve onların belirlediği kurallara uygun olarak tekrar üretildiği müddetçe doğal kabul edilebileceği gibi devamlıı̆ının da sağlanması oldukça mümkündür (Şakrak 2018). 


\section{$\operatorname{arts}=$}

Son dönemde üretilen post apokaliptik filmlerde yer alan canavarlara bakıldığında ise; bu canavarların bireysel etkilerden çok toplumsal dönüşüme yönelik etkilerinin olduğunu söyleyebiliriz. Geçmişte üretilen pek çok yapımda hem görünüşünü gözlemleyebildiğimiz hem de hangi güdüler veya gerekçelerle hareke† ettiğini bildiğimiz canavarlarla karşılaşırken; günümüz yapımlarında bunun tam tersi bir durumun olduğunu söyleyebiliriz. Geçmişin canavarları bireysel korkulara seslenen, korkulacak yönlerinin temeline doğadan kaynaklanan (kurt adamlar, vampirler gibi) güçleri bulunan varlıklarken; günümüz canavarları kitleleri tehdit eden ve kitlesel korkulara (zombiler, salgınlar veya bahsedilen pek çok muğlak canavar gibi) yönelen yaratıklar olarak karşımıza çıkmaktadır. Bu canavarlar büyük ölçüde tüketim ve iletişimle ilişkili bir yapı içerisinde seyirciye sunulmaktadır. Bir başka ifadeyle modern dünyanın toplumlarına sunduğu böylesi bir tüketim ve iletişim ortamının ortan kalkması ile canavarların aslında toplumun kendisi olabileceği iletisi sunulmaktadır.

\section{KAYNAKÇA}

Bilici, M. V. (2007). Hollywood filmlerindeki apokaliptik temalar: Sinema, popüler kültür ve din. Milel ve Nihal: İnanç, Kültür ve Mitoloji Araştırmaları Dergisi, $4(2), 139-161$.

Boz, M. ve Takımcı, D. (2019). Amerikan Post-Apokaliptik Bilimkurgu Sinemasında Kıyamet İdeolojisi (1924-2000). Akdeniz Üniversitesi İletişim Fakültesi Dergisi(31), 377-403.

Campbell, J. (2017). Kahramanın Sonsuz Yolculuğu İstanbul: İthaki Yayınları.

Castells, M. (2013). Ağ Toplumunun Yükselişi / Enformasyon Çağı: Ekonomi, Toplum ve Kültür Cilt 1. İstanbul Bilgi Üniversitesi Yayınları.

Ekinci, B. T. (2015). Toplumun Korkulari: Zombi Filmleri ve Ölümcül Deney Serisinin Analizi. Global Media Journal: Turkish Edition, 6(11), 220-239.

Hansen, M. B. (2009). The mass production of the senses: Classical cinema as vernacular modernism Disciplining Modernism (pp. 242-258): Springer.

Landis, J. (2011). Monsters in the movies: 100 years of cinematic nightmares: Dorling Kindersley Ltd.

McNally, D. (2015). Piyasanın Ucubeleri Zombiler, Vampirler ve Küresel Kapitalizm (i. Çetin, Trans.). Ankara: Dipnot Yayınları. 
Moretti, F. (2005). Mucizevi Göstergeler (Z. A. Akatlı, Trans.). İstanbul: Metis Yayınları.

Oskay, Ü. (2014). Çağdaş Fantazya, Popüler Kültür Açısından Bilimkurgu ve Korku Sineması. İstanbul.

Paxson, P. (2018). Mass communications and media studies: An introduction. ABD: Bloomsbury Publishing

Skult, P. (2015). The Role of Place in the Post-Apocalypse: Contrasting The Road and World War Z. Studia Neophilologica, 87(sup 1), 104-115.

Şakrak, B. E. (2018). Batı Kökenli Popüler Korku Filmlerindeki Fantastik Korku İkonları: Toprağin Kabul Etmediği Lanetliler. Motif Akademi Halkbilimi Dergisi, 11 (24), 178-193.

Thomas, K. (2010). Haitian Zombie, Myth, and Modern Identity. CLCWeb: Comparative Literature and Culture, 12(2). doi:https://doi.org/10.7771/14814374.1602

Topçu, Y. G. (2001). Dracula'da Vampir Kadın. Gazi Üniversitesi İletişim Fakültesi Dergisi, 10, 127-145.

Voigts, E. ve Boller, A. (2015). Dystopia, Science Fiction, Post-Apocalypse.

Wojcik, D. (1997). The end of the world as we know it: Faith, fatalism, and apocalypse in America: NYU Press. 